821.163.41-1.09 Радичевић Б. https://doi.org/10.18485/msc.2018.47.2.ch36

Ненад В. НИКОЛИЋ ${ }^{*}$

Оригинални научни рад

Универзитет у Београду

Примљен: 31. 10. 2017.

Филолошки факултет

Прихваћен: 27. 12. 2017.

\title{
КАРНЕВАЛИЗАЦИЈА У „ЂАЧКОМ РАСТАНКУ” БРАНКА РАДИЧЕВИЋА
}

\footnotetext{
У раду се анализирају карневалски елементи кола (бербанског и националног) у „Бачком растанку” Бранка Радичевића, узевши у обзир општи смисао мотива растанка који у себе укључује поглед у прошлост као сету и ишчекивање будућности у знаку наде. Од почетка присутну, лирски субјекат свест о времену и смрти доследно потискује, најпре сећањем на идилу, потом карневалским колима, да би на завршетку предност била дата националној идеологији у знаку секуларног хилијазма.

Кључне речи: време, карневализација, коло, нација, Бранко Радичевић, растанак, Срби, смрт.
}

„Ђачки растанак”' једна је од најпознатијих и најомиљенијих песама Бранка Радичевића. Њена посебно позната места су кола, којих има два краће бербанско:

Коло, коло, свирац свира,

Нога земљу не додира,

„Ситно, брате, ијујују!”

Момци чили подвикују:

„Свирац свира,

Не да мира,

А још више девојчице,

Њине очи и ножице,

Деде, брате, ијујуј!

Де поскочи, не лудуј,

Ко би јако момак био

Па се не би помамио!

Ао селе босонога,

\footnotetext{
" Студентски трг 3, 11000 Београд, Србија

1 „Бачки растанак” наводи се по издању: Б. Радичевић, Сабране песме, пр. Д. Иванић, Београд: Српска књижевна задруга, 1999.
} 
Зла ти маја дозлабога,

Не дала ти чарапица

Ни лагани папучица,

Да учиниш клепа-клапа -

За тобоме, душо, скапа.

Охо, селе, вита стаса,

Држ’ се браци око паса,

Коловођа колом вија,

Коло лети, зној пробија,

Ал' у твоји недри туде

Окле снега до две груде?

Чудо, селе, дивно чудо,

Ала би се млађан грудоิ!”

Коло, коло, наша дика,

Пушка пуца: цика, цика!

Па све тако пуцај, бери,

Певај, играј до вечери,

А кад сунце веће седа,

Бесна момчад још се не да,

Иде кући, подвикује,

Пуни пушке, попуцује,

Свирац свира, мома поје:

„Коловођа, злато моје!”

Па у крчму, те до зоре,

Коло игра, песме c' оре,

А у зору с' зајухуче,

Удри опет ка̂ и јуче (198-237).

и дуже ђачко, које се може назвати и национално, јер „коло о берби исто је као и свако друго коло; ђачко играње треба и да је специфично српско, да има нарочито национално обележје” (Поповић 1999: 51).

Тамбур, тамбур, ситна тамбурице,

Удри, побро, у сићане жице,

Данас има, а сутра нас нема,

Ајд' у коло, ко ће ту да дрема?

Он у среди у тамбуру бије,

А коло се око њега вије,

Ао брацо, ао тамбурице,

Удри жешће у те ситне жице,

Ситне жице - ситнији кораци,

Нек се знаде кад играју ђаци!

Ој ви српски витезови,

Ви змајеви, соколови,

Та има вас на иљаде,

Ал' бројити немам каде,

Та кад би вас све бројио,

Кад би јадан винца пио!

Ој Шубићу,

Јуранићу, 
Турске главе

Беу траве,

Мачи ваши бритка коса,

Крвца ваша беше роса,

Роса росну, јавор с' диже,

Певац иза њ гусле здеља,

Па бугари што сте били,

Што л' десницом починили,

Дела ваша сунцу равна

Неће скрити нојца тавна.

Ноћи, ноћи, тавна ноћи -

Ко би Србу у помоћи?

Ој Чупићу, љута гујо,

Ој Ћурчијо, мрки вујо.

Ао Луко,

Турска муко,

Ао Петре

Плаи ветре,

Што довати турско море

Па о српске разби горе!

Ој Поцерче, ој Милошу,

Наш соколе, славо мила,

Ал' на славу Турком лошу,

Јер им сломи пуста крила,

Сруши Дрини у дубину

Ону страшну орлушину:

Ви звездице нашег неба,

Што сијасте ко̂ што треба,

Звезде трепте, звезде сјају,

Али данка још не дају,

Ђорђе дође, сунце грану,

А Србији дан освану.

Коло, коло

Наоколо,

Виловито,

Плаовито,

Наплетено,

Навезено,

Окићено,

Зачињено,

Брже, браћо, амо, амо

Да се скупа поиграмо.

Србијанче, огњу живи,

Ко се тебе још не диви!

Рваћане, не од лане

Одувек си ти без мане!

Ој Босанче, стара славо,

Тврдо срце, тврда главо,

Тврд си као кремен камен,

Де станује живи пламен! 
Ао Еро, тврда веро,

Ко је тебе јоште теро̂?

Ти си кано итра муња

Што никада не покуња.

Ао Сремче, гујо љута,

Сваки јунак по сто пута!

Црногорче, царе мали,

Ко те овде још не фали?

Мачем бијеш, мачем сечеш,

Мачем себи благо течеш,

Благо турска глава сува,

Кроз њу ветар горски дува.

Ој соколе Далматинче,

Дивна мора дивни синче!

Oj ти красни Дубровчане,

Наш и данас бели дане,

Та са песме из старине

Пуне славе и милине!

Ој Славонче танани!

Банаћане лагани!

Ој Бачвани, здраво, здраво,

Ко ј’ у песми већи ђаво!

И ви други дуж Дунава,

И ви други де је Драва,

И сви други тамо, амо,

Амо да се поиграмо!

Ватите се кола тога,

Од вишњег је оно Бога:

Руком држи братац брата,

Близу срца њега вата.

Свирац свира,

Срце дира,

Рука с' диже на посао,

Да л' ће коме бити жао?

Нога лупа, диже пра,

Наоколо свуда стра.

Нога лака, срце здраво,

Коло лети, коло ђаво,

Поскочица ђаволица,

Што је тела, то и смела,

Ал' је жеца одолела.

Ој ти секо

Каิно млеко

Белолика,

Каิно винце руменика,

Ка̂но паун поносита,

Ка̂но јела, селе вита,

Амо брже па наточи,

Да ти браца боље скочи, Амо, селе, а за Бога, 
Видиш е сам изнемога̂,

Тако, злато, тако, тако,

Сад је коло играт лако,

Амо, чедо милооко,

Дај да т' љубне браца око.

Она бежи - за њом с' вини,

Љубни, брате, пипни, штини,

Така игра, шала така

Таман, брате, за јунака!

Ајдук Вељко зна љубити,

Ал’ и сабљом дивно бити,

Ајдук Вељко љути вуја,

Турци стадо јагањаца,

Ајдук Вељко ка̂ олуја

Кад у јесен из кланаца

Свати лишће то по гори,

Па обори,

Крши грање, па силена

Чупа раста из корена -

Сече Вељко и натиче,

Гони, стиже што измиче,

Сече аге посред паса -

„Ала, Ала!” оде с гласа,

Ломи коње и јунаке,

Чини јаде свакојаке,

Кушља тлачи, сабља сева, Кликће Вељко, Туре зева,

О тле чалма, о тле глава,

Ал' под небо српска слава!

Ведро небо на високо,

Равно поље на широко,

А на пољу два окола,

Средом гледни сина гола,

Татарин је - ватра жива -

Прети мачем па дозива:

„Ој Угрине, курво, амо, Амо да се огледамо!"

Угри гледе сви у траву,

Јакшић горе диже главу,

Вата штита гвоздена,

Вата мача пламена,

Лако врда, маше лако, Али бије врло јако,

Сада звекну, сада ману,

Сада севну, сада плану,

Доле паде Татарин,

Погуби га Србљанин!

Плао коло, тече зној,

Де још мало, брате мој!

Мало цупни, 
Мало лупни

Да се тресе цео дом,

Оком севни,

Грлом певни,

Као муња, као гром -

Стреле, копља, бојни мачи, Јунак бије, а коњ тлачи,

Звека,

Јека,

Вриска,

Писка,

Гором, долом, јунак врви,

Гора, дола, сва у крви.

Све од мора Јадранскога

И од града тог Белога,

Све од оног Дренопоља

Што с' отеже мору Црну,

Све то Душан себи згрну,

То учини божа воља,

Душан, Душан, бујна река, Србин јунак па до века!

Ао века,

Млада века,

Сад на коњу, сада пешке,

Сад код Јаше, сад код сешке,

Сад при чаши, сад у колу -

Гледај, боже, браћу голу!

Голи брацо, што си стао,

Ваљда неси већ сустао,

Цупни, скочи,

Ситно крочи,

Па заведи,

Па проведи,

Опа цупа,

Па на ћупа!

Ал' ти c', брате, светле очи,

Али ништа, само точи,

Кака чаша така срећа,

Дајде ону, та је већа,

Још и у ту винца ледна,

Мени треба јоште једна -

Браћо мила, здраво, здраво!

Ја сам други кнеже Паво̂:

Паво̂ беше соко сиви,

Чудио се сваки живи,

Е он шчепа Туре устим',

А два друга рукам' пустим,

Па заигра по мртваци

Као муња по облаци;

Ја у руци једној чашу, 


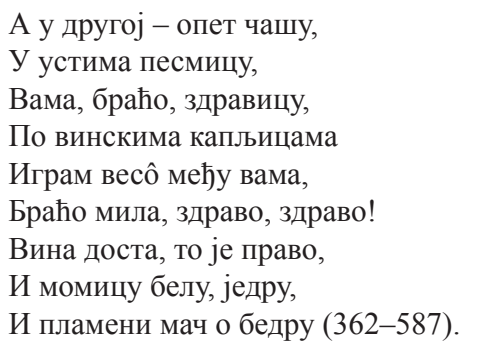

Често цитирана - нарочито део националног кола у којем се набрајају Срби по покрајинама, чиме је Радичевић целом колу дао „карактер свесрпски, позајмио му идеју националног уједињења" (Поповић 1999: 51) - кола у „Ђачком растанку” нису била сагледавана имајући у виду доминантан смисао Радичевићеве песме одређен мотивом растанка. У наслову, везан за једно доба - ђачко - растанак је пре свега догађај у времену, иако је истовремено и растанак са простором (што је прецизно одражавао наслов Радичевићеве ране верзије песме „Опроштај од Карловаца”). Временски одређен, растанак неизбежно упућује на временост јунака који се растаје: његову прошлост која се призива у сећање, те ишчекивање и наду положену у будућност. Таква позиција лирског субјекта посебну пажњу усмерава на његову садашњост, која је - као тренутак растајања - преломна. Какву улогу у тој граничности егзистенцијалне ситуације имају кола?

Коло је, у народној традицији коју лирски субјекат „Ђачког растанка” вишеструко призива, схватано као карневалски простор. У одредници „Поскочица" Српског рјечника Вук Караџић упозорио је да је простор кола јасно ограничен и омеђен:

Поскочица, f. cautus saltatorius. Највише се говори у млож. броју поскочице, т.j. као кратке пјесме, што момци говоре и подвикују у колу кад играју, н.п.

\author{
„Опа цупа \\ „Данас сутра. \\ „Никад ништа \\ „До издрти \\ „Опанака. - \\ „Ај уј не лудуј \\ „С туђом љубом не другуј: \\ „Туђа љуба пасја вјера, \\ „Намамиће, превариће. - \\ „Скочи коло дупе голо. \\ „Како радиш и горе ће. - \\ „'Опа цупа \\ „Под њом рупа. - \\ „Мучи враже, \\ „Ко ти каже? \\ „Није једна \\ „Веће двије.
}


Поскочице су готово све тако срамотне, да и осим кола не смије нико ни поменути; а у колу и нико за срамоту не прима. Младе и ђевојке, старци и бабе, учине се као да и не чују што момци говоре. Ја сам слушао и гледао (у Јадру у Беговој Љешници) ђе Турци сједе, а Србљи око њи играју и подвикују:

„Опа цупа данас сјутра,

„Наше ноге, Турска земља;

„За то Турци и не маре;

„Силне баше говна једу,

„А субаше таслаишу (Караџић 1818: 611).

Слобода момака да о опсцености говоре условљена је прећутном сагласношћу стараца и баба, који су регулатори друштвеног понашања и мерило норме. Поред слобода везаних за телесност и сексуалност, допуштене су и слободе које се тичу односа Срба и Турака, дакле односа међу народима и вероисповестима, и - још важније - између власти и поданика. Тиме народно коло и по Бахтиновој дефиницији припада карневалском простору, увек тесно повезаном са празничним временом, који је „,bio nešto kao privremena obustava dejstva čitavog zvaničnog sistema sa svim njegovim zabranama, i hijerarhijskim barijerama" (Бахтин 1978: 104). И за народно коло - како га је Вук описао наведеним примерима поскочица - била је важна „drama telesnog života (snošaja, rođenja, rasta, jedenja, pijenja, pražnjenja)" (Бахтин 1978: 103), а такође и „,njegova istina smeha snižavala je vlast, sjedinjavala se s kletvom - psovkom" (Бахтин 1965: 108).

Међутим, ако је смех „suštinska unutrašnja forma koja se ne može zamenjivati ozbiljnošću a da se ne uništi i ne pokvari, sam sadržaj istine otkrivene njim" (Бахтин 1978: 109), како се карневалска кола за која драма телесног живота заиста није „drama individualnog tela i pojedinačnog materijalnog postojanja, već drama velikog narodnog tela koje rađa, za koje rođenje i smrt nisu apsolutni princip i kraj, nego samo momenat njegovog neprekidnog rasta i obnavljanja" (Бахтин 1978: 103-104) слажу са гледањем на смрт као неопозиви крај, којим „Ђачки растанак” почиње (9-43), а које се појављује и непосредно после другог, националног кола (589 и даље), и како се то што је карневалски смех као суштинска унутрашња форма „оtvarao oči za novo i buduće” (Бахтин 1978: 109) слаже са потребом да се приликом евоцирања разговора о српској будућности пређе на патос?

Колико смо спрама месечине Тако, браћо, ми стајали пута, Сећали се прелепе старине,

Проклињали сад времена љута,

Па се клели ноћом и тишином,

Клели, браћо, Богом и истином,

Ударити тешкој маглуштини,

Маглуштини, тешкој облачини,

Ударити оној страшној ноћи,

Та лудилу и клетојзи злоћи,

Па пробудит ону српску зору 
Зору ону, онај данак бели,

У дивноме тако разговору

До по ноћи често смо провели,

Онда дому сваки, и ја своме,

Још се моли Богу истиноме

Да што пређе оде ноћна тама,

Да што пре се посастанем с вама (687-704)

Постоје ли у „Ђачком растанку”, онда, две истине о свету: карневалска и истина патоса? Обе су супротстављене званичној, владајућој истини, обе подразумевају слободу од званичних норми, чиме успостављају однос према садашњости, док су, извирући из прошлости, на будућност усмерене посредно (карневалска) и непосредно (патос), а пресудно се разликују по присуству лирског субјекта у њима. Поздрављајући се са друговима пред јутарњи, коначни одлазак, лирски субјекат на самом крају песме поручује каква будућност треба да буде и какав у њој ваља да је однос према прошлости:

Сећајте се мене, друга свога, Сећајте се красна доба тога, Ох заклетве оне дивне, свете, Браћо мила, заборавит нете, Ње с' сећајте увек и свакада, Мене млада само кадикада, Само онда кад чашу узмете, Па весели до дна испијете,

Тада само, тада веселога

Сетите се, браћо, друга свога (717-726)

Будуће сећање на лирског субјекта, на веселог друга, треба да остане у карневалском, празничном времену, да буде повремено, док сећање на заклетву да се буди српска зора треба да буде стално, свакодневно. Национално ce, тако, поставља као оно што прекорачује лично, и то сасвим другачије него што је велико карневалско народно тело себи подређивало сваког појединца у колу. Желећи да буде задржан у сећању само као весели друг, какав однос лирски субјекат успоставља између карневализације и своје времености?

Бербанско коло не припада садашњости лирског субјекта који се растаје од ђачког доба, него долази из његовог сећања на бербу која обележава хронотоп у којем смрт није страшна јер је део природног ициклуса народног тела - „Дођи, види, чуј, па ајд’ у гроба” (183) - а рад представља лепоту и задовољство - „Гледај сада убавога рада” (189), „Живо с’ ради, ал' нико с' не мори" (193) - чиме се граничи са идилом, за коју рад такође није мука и у којој нема смрти. Међутим, наглашеном телесношћу, бербанско коло удаљава се од идиле и добија бахистичку нијансу. Иако у њему нема непосредног евоцирања вина, прелазак кола у крчму уноси посредно и ту димензију. Бербанско коло је и симбол вечитог понављања (234-237): за њега време не постоји, нема ни прошлости, као ни будућности. Сећање на њега се, стога, као сећање на вечиту садашњост приближава оним евоцирањима идиличне прошлости којима лирски субјекат „Ђачког растанка” потискује своју време- 
ност којој је изручен чином растајања. Доносећи са собом осећање времена, растанак доноси и свест о смрти: зато је закономерно што „Ђачки растанак” почиње сликом гроба као неопозивог краја. Од те свести лирски субјекат уклања се у сећања на идилу у којој није било времена, па ни смрти - у којој је било „ка у рају” (61).

Бербанско коло, дакле, карневализацијом, којом укида временост и смртност лирског субјекта, представља један од израза жеље лирског субјекта за непроблематичним постојањем, па онда и за не-растајањем. Ту се карневализација додирује са идилом: заједничко им је циклично осећање времена из којег проистиче потискивање свести о смрти, али док у идили нема сексуализованости, у карневалском колу телесно је одређено мушком жељом према девојкама, доследно схваћеним као телесна бића, еротизованим усмеравањем пажње на поједине делове њихових тела, да би се у ноћном наставку кола у крчми појавиле и друге, за карневалско тело по Бахтину важне функције (пре свега пијење). Зато је тренутак у којем се идила претвара у карневал тренутак у којем је у „Ђачки растанак” продрло време, али које се карневалским колом потискује. Другим речима, карневализација коју доноси бербанско коло знак је да идила више није могућа. За разлику од идиле која не зна за време и смрт, карневал управо у односу на време, смрт и уобичајени поредак остварује свој значај. Људи који живе у идили немају потребу за карневалом. Претапање идиличног топоса рада као задовољства у карневалску узвитланост тела обележава тренутак у којем телесност избија у први план. То је тренутак у којем се појављује потреба за антипонашањем, које у себи чува свест о свакодневном поретку који је насупрот потпуне природности идиле премрежен различитим ограничавајућим нормама. На тај начин, бербанско коло је тренутак у којем се кроз карневализацију и наглашену телесност односа мушкараца и жена открива проблематичност унутар наизглед идиличне прошлости од које се лирски субјекат опрашта.

Почињући свој растанак на гробљу, лирски субјекат је већ у тренутку у којем је започео растајање од ђачког доба идилу био напустио: само тако се, уосталом, уношењем времена у поимање лирског субјекта, и могла јавити свест о растанку. Као спољашње време - завршетка школовања - оно је постало и унутрашње време лирског субјекта који се нужношћу напуштања Карловаца осетио, кроз ту промену, као биће у времену; гроб над којим стоји томе додаје димензију човека као бића ка смрти, односно коначности личног времена. Бербанско коло, обележавајући прелазак из идиле у еротизованост, показује онај тренутак у прошлости када су први пут у дотицај дошли идила и време: цикличност кола и отвореност према свету били су покушај да се унутар не-више-идиличног света очува непроблематичност. Која је, као и свака карневалска непроблематичност, привидна будући немогућа без искуства смрти и времена. Телесност бербанског кола блиска је отворености народног кола, али су деминутиви и употреба метафора, чиме се ублажа- 
ва отвореност попут оне у народном колу, ${ }^{2}$ а која је и за Бахтина нужност карневалске гротеске, оно чиме се бербанско коло од карневала приближава углађенијој, грађанском свету прихватљивијој еротици.

Укратко, у првом, бербанском колу, оно што би припадало карневалском осећању света само је тренутак између идиле и грађанске еротике: карневализација служи да се сачува изгубљена без-смртност идиле, али еротика обележава неуклоњивост свести о смрти, и то смрти као коначног чина, а не смрти као дела циклуса великог народног тела, премда је баш таквим схватањем смрти почело сећање на бербанско коло. Тако је кретањем од идиле преко карневала до еротике из природе и народног тела израсло осећање појединачности лирског субјекта, одређеног сопственом временошћу као путем ка личној смрти.

Упоредо са тим осећањем и потискивањем времености, лирски субјекат се од почетка, унутар свог сећања на ђачке дане, евоцирајући далеку националну прошлост (110 и даље), препуштао не само времену, већ и осећању узвишености херојске смрти. Наивност томе посвећених Радичевићевих стихова које је Кашанин добро окарактерисао као ђачко позориште, ${ }^{3}$ може се објаснити њиховом смештеношћу у егзистенцију која упоредо слави херојску смрт и потискује свест о домашају времена и коначности смрти: ђак који слави херојску смрт заправо не осећа тежину својих речи, у њима националну идеју која би да смрт учини највеличанственијим јавним догађајем наткриљује егзистенцијално становиште за које је смрт лична и, отуда, коначна, али које себе не може обликовати у складу са тим, него у карневалу тражи заборав времена и смрти. У националном колу се та два становишта обједињују. Оно, за разлику од бербанског кола, не припада сећању лирског субјекта, него његовој садашњости. Оно је завршетак последњег весеља у кафани са друговима (308 и даље). Такође простор неспутане слободе (468469), национално коло ту слободу користи да кроз слободне асоцијације и повезивање националне и винске тематике евоцира славну прошлост. Лирски субјекат лако са ђака прелази на витезове, да би потом позвао у коло Србе из свих покрајина у којима живе, повезао националну са телесном слободом и одмах се сетио Хајдук Вељка, а за њим и других великана, Јакшића и цара Душана, да би се на крају поистоветио са кнезом Павлом. ${ }^{4}$ У евокацији чувеног описа грофа Ђорђа Бранковића како је кнез Павле играо држећи у зубима мртвог Турчина (а којем је додат и по још једна мртав Турчин у свакој руци), ${ }^{5}$ Турци су замењени чашама, песмом и винским капљицама. Уз вино

\footnotetext{
2 Занимљиво је да је у Вуковој одредници „Поскочица” у првом Српском рјечнику, иначе богатом вулгаризмима, присутан блажи облик поскочице која је постојала и у експлицитнијем виду (Караџић 1980: 65).

3 „Радичевићеви хајдуци нису хајдуци, већ маскирани ђаци, његово оружје (кад га има) не само што не убија и не скида главе, већ и не пуца и не сече - то није оружје из живота, већ из Бургтеатра" (Кашанин 2001: 8).

${ }^{4}$ Радичевићев асоцијативни поступак у том делу „Ђачког растанка” одлично је описао и објаснио Павле Поповић (1999: 51-55).

5 У преводу Милорада Павића то место из четврте књиге Славеносербских хроника гласи: „Такође и кнез Павал на игру поскочицу беше понуђен, и ускочивши усред хора у покрету, које у облику венца заокружено беше, са сред кола удављеног турског непријатеља, који је тамо лежао,
} 
и белу мому, лирски субјекат жели и пламени мач о бедру: у овом контексту изразито двосмисленим симболом у којем се укрштају херојско и сексуално, завршава се национално коло. Потом следи прекид (и графички означен), па се по одласку кола лирски субјекат и његови другови присећају својих мртвих другова - Арсе, Симе и Јулија. Сећању на њихову смрт поново је супротстављена слика идиле, али уз свест да је њено време неповратно прошло: „Цвеће љупко ми смо млади брали, / Песме славља убаве слушали, / Цвеће лежи у артији суво, / Песме славља ветар је одувоิ" (675-678). Уместо непроблематичности егзистенције, онемогућене корозивним деловањем времена, нуди се обећање непроменљивости - „Ал’ ми ћемо као што смо били / Један другом свагда бити мили" (679-680) - које подразумева време, прихвата га, и опире му се захтевом за постојаношћу у променљивим околностима. Како „дужности да себе саме одржимо држећи своја обећања пријети опасност стоичког укрућивања пуке постојаности ако се та дужност не освјежава завјетом да се одговори на једно очекивање, штавише на молбу која долази од другога" (Рикер 2004: 275), то је и тренутак у којем се припрема истина која ће бити изречена са патосом, истина о посвећености нацији и буђењу српске зоре, која мора бити значајнија од веселог друга. Тако је она постављена изнад сваке појединачности, као начин да се превазиђе то што „суморна анализа обећања које смо управо извршили наглашава цезуру [...] између поштовања правила и поштовања особа” (Рикер 2001: 276).

Карневалска национална истина тако је напуштена, иако смисао недовољно одређене метафоре „српске зоре” мора бити одређиван уз ослањање на „коло у колу” националног кола, које упућује на јединство свих Срба. Али, док је за карневалску истину нација била једно усковитлано народно тело, у истини изреченој са патосом нащија надилази свако појединачно тело. Она више не пролази кроз појединце који својом телесношћу учествују у општем испољавању народног тела као тела нације, него их потчињава себи. Нација се зато, иако је не може бити без народног тела, одваја од тела и постаје идеја, за коју српска тела постају средства. То је заправо већ и наговештено у националном колу, јер и тамо појединачна тела отелотворују идеје различитих Срба: Србијанца (живог огња), Хрваћана (не од лане и без мане), Босанца (славног од старине, тврдог срца и главе)... Телесност националног осећања у колу - „Руком држи братац брата, / Близу срца њега вата” - израз је доминантне садашњости, која се ослања на прошлост, док се будућност експлицитно не ословљава. Коначно екстатично поистовећивање лирског субјекта са кнезом Павлом (,Ја сам други кнеже Павоิ”) чини прошлост живим делом садашњице, али из које је нестало тежине, у складу са особинама лирског субјекта, веселог ђака. Зато Хајдук Вељко и може бити „љути вуја”: оксимороничност херојске атрибуције и деминутива метафоре вука-хероја свакако је последица одсуства епског духа код Радичевића, али у „Ђачком

зубима својим са земље подиже не додирнувши га руком. И у том колу док су се посматрачи више дивили неголи смејали, многобројна поскакивања са мртвим телом у зубима изводио је кнез тако у колу, мушком одважношћу и снагом начинивши се сличан Ираклију, латинским пак језиком названом Херкулу” (Павић 1970: 423). 
растанку" то мање смета него, на пример, у стиховима друге књиге његових песама. Јер, тамо је то требало да буду епски стихови, овде је то израз лирског субјекта, који није епски. Због тога вишесмислена симболика „пламеног мача о бедру”, будући потребан уз „момицу белу, једру”, у „Бачком растанку” ипак више упућује на сексуално него јуначко, слично начину на који се лирски субјекат поистовећује са кнезом Павлом. Мртви Турци замењени вином и песмом нису израз карневализације макабристичке слике: искасапљена тела била су честа у народној смеховној традицији (Бахтин 1965: 210), али су се у њој та тела од непомичних и трајно мртвих преображавала у амбивалентна тела која у себи уз смрт садрже и ново рађање, баш као што и „slike mokraće i izmeta su ambivalentne kao i sve slike materijalno-telesnog dole: one istovremeno i unižavaju - usmrćuju, i preporođuju - obnavljaju, one su i blagoslovene i unižavajuće, u njima su neraskidivo spleteni smrt i rođenje" (Бахтин 1978: 166). Сплетеност смрти и рађања није био смисао игре кнеза Павла: како је њу Бранковић описао у Славеносербским хроникама, она је била израз кнежеве наднаравне снаге, потпуног тријумфа и апсолутне надмоћи над пораженим непријатељем, док призивање те сцене у Ђачком растанку и замењивање мртвих Турака вином и песмом, напротив, води забораву смрти као смрти. Оно што је било тешко - и дословно: мртав Турчин у рукама и зубима - постаје врло лако: чаше и песма. Уклањање тежине из света зато је мање знак карневализације - јер није смрт преплетена са рађањем, већ одстрањена из свести - а више тривијализащије. На тај начин је и само вино тривијализовано - лишено култних својстава - па ће и у националном колу - као и у бербанском - бахистичка нијанса остати тек слаби наговештај, због чега не само херојска, већ и сексуална симболика пламеног мача о бедру бледи у корист реторичке упечатљивости израза, који од карневалске потпуне слободе води ка грађански прихватљивој еротици, као што и у пољу политичке слободе истину о српском јединству, сведену на игру, чини мање обавезујућом. Због тога је неопходно да истина о буђењу српске зоре буде изречена са патосом у простору свакодневице, складно томе што су и смрти које лирски субјекат детаљно евоцира после завршетка националног кола, односно напуштања карневалског простора, обичне, људске смрти, од болести или несрећа. То су смрти које уз свест о ограничености човековог живота не призивају идеју жртве којом се надилази овоземаљски живот, садржану у херојској смрти, нити су део карневалом упризореног великог народног тела у којем су смрт и рађање у равнотежи одвијања живота који је изнад свега. То су доследно личне смрти, над којима нема ничега. Зато је потискивање појединаца у име националног израз одустајања од сопствености одређене временошћу као путем ка не-херојској смрти у име националне идеје која се јавља као најопштија есхатологија. Управо изразитом усмереношћу ка будућности и одсуством конкретног садржаја (чак и оног које би упућивало на српско јединство, тако снажно постулирано у националном колу) „српска зора” је пре свега секуларизована „вера у надсветски спас” (Сафрански 2015: $96)$ - складно томе што се и национализам може описати као секуларизована, политичка религија (Велер 2002: 32 и даље). 
Постављајући буђење српске зоре као општи задатак који надилази сваку појединачност и задржавајући сопственост у карневалском простору, лирски субјекат је показао да карневалско коло, иако јесте један од начина на који „друштвена контемпоралност нуди заштиту од фурије нестајања" (Сафрански 2015: 96), више није довољно да се савлада осећање личне смртности и коначности: јер, притисак времена у тренутку када мора доћи до коначног растанка (710 и д.), када се физички мора изместити из простора и напустити другове са којима је карневал дељен, чини терет личне времености претешким. Заклетва да се буди српска зора, долази као спас: за разлику од карневала који у садашњици ослобађа терета времена - док траје, али се мора завршити, што је још један израз надмоћи времена - заклетва да се буди српска зора будућност од кретања ка смрти претвара у кретање ка идеалу и одсудно осмишљава све будуће, не потискујући већ прихватајући време, али као заједничко време нације. Лично време, време ка смрти, нестаје и у њему, баш као што је нестајало и у карневалу, али док се карневал морао завршити, времену нације припада будућност. Прелазак са карневалске истине о Србима на истину која се изриче са патосом и која треба да буде свакодневна коначни је израз немогућности лирског субјекта „Ђачког растанка” да прихвати своју личну временост и смртност, и трећа медијација покушаја да их се ослободи: сећање на идилу било је неуспешно јер идила није могућа уз притисак времена које лирског субјекта изводи из простора ђаковања и одваја од прошлости, карневалска кола била су неуспешна јер су временски и просторно ограничена, тек патос нације може пружити потребну утеху: за разлику од идиле (постојеће у сећању на прошло) и карневала (апсолутизоване садашњице), он је задатак за будућност.

\section{ЛИТЕРАТУРА}

Бахтин 1978: M. Bahtin, Stvaralaštvo Fransoa Rablea i narodna kultura srednjega veka i renesanse, Beograd: Nolit.

Велер 2002: Х. У. Велер, Национализам: историја - форме - последице (Nationalismus. Geschichte - Formen - Folgen), Нови Сад: Светови.

Караџић 1818: В. С. Караџић, Српски рјечник истолкован њемачким и латинским ријечима, Беч.

Караџић 1980: V. S. Karadžić, Crven ban: erotske narodne pesme, izabrao i priredio B. Jastrebić [на основу: Српске народне пјесме из необјављених рукописа Вука Стеф. Караиића. Књига пета: особите пјесме и поскочице, Београд: САНУ, 1974], Beograd: Prosveta.

Кашанин 2001: М. Кашанин, Између орла и вука (Бранко Радичевић), Судбине и људи: огледи о српским писиима, Загреб: Просвјета, 8-31.

Павић 1970: М. Павић, Историја српске књижевности барокног доба (XVII и XVIII век), Београд: Нолит. 
Поповић 1999: П. Поповић, Бранко Радичевић, Нова књижевност II: Od Бранка до Шантића, приредио П. Палавестра (Сабрана дела Павла Поповића, књ. 6), Београд: Завод за уџбенике и наставна средства, 1-107.

Радичевић 1999: Б. Радичевић, Сабране песме, прир. Д. Иванић, Београд: Српска књижевна задруга.

Рикер 2004: П. Рикер, Сопство као други (Soi-même comme un autre), Београд - Никшић: Службени лист СЦГ - Јасен.

Сафрански 2017: R. Zafranski, Vreme. Šta ono čini nama i šta mi činimo od njega (Zeit. Was sie mit uns macht und was wir aus ihr machen), Beograd: Geopoetika izdavaštvo.

\author{
Nenad V. Nikolić
}

CARNIVALISATION IN BRANKO RADIČEVIĆ'S THE STUDENTS'FAREWELL

(Summary)

The paper analyses the carnivalesque elements of the wheel dance (wine harvest and national dances) in The Students' Farewell by Branko Radičević, with respect to the general sense of the farewell motif which includes a view into the past as melancholy and the expectation of the future as a sign of hope. The lyrical subject consistently represses his consciousness of time and death, present from the beginning, first through a remembrance of the idyll, then through the carnival dances, and finally he gives precedence to national ideology in the form of secular chiliasm. 